\title{
Integrating solar energy in Rome's built environment: A perspective for distributed generation on global scale
}

\author{
Francesco Meneguzzo, ${ }^{*[b]}$ Mario Pecoraino, ${ }^{[c]}$ and Mario Pagliaro*[a] \\ This article is dedicated to Professor Livio de Santoli, University of Rome La Sapienza, for all he has done to promote solar energy \\ and energy efficiency in Italy's and Rome's historic built environment
}

\begin{abstract}
Large-scale integration of solar energy technologies in Rome's built environment epitomizes the needed general adoption of distributed generation via functionalization of buildings of all size and end use across the world, to become active energy generators and no longer energy users only. This paper identifies selected technology solutions and critical policy and educational initiatives to effectively achieve within the next decade (2018-2027) the widespread uptake of decentralized solar energy systems in the built environment on a global scale.
\end{abstract}

Keywords: solar energy $• \mathrm{BIPV} \cdot$ energy transition $\bullet$ energy efficiency $\cdot$ photovoltaics

\section{Introduction}

A new model combining the competing dynamics of oil price, economic growth and extraction costs, ${ }^{[1]}$ suggests that investments in new renewable energy power needs to be urgently increased to cope with the global consequences of the resulting energy and economic scenario.

With the global population growing along the current trajectory, in the 2016-2025 decade about 800 million people will add to the world's population. Correspondingly, in order to feed the "natural" growth of the gross domestic product (GDP) identified by the above model, by 2025 the total energy consumption should increase by about 1,700 million tons of oil equivalent (MTOE) per year. Even to keep the oil fraction in the energy mix at the 2015 level (around 33\%), this means that more than 11 additional million barrels per day will have to be added to current

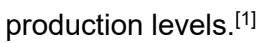

Consuming energy for space and water heating and electricity for cooling, lighting and powering domestic appliances, buildings are responsible for a significant share of global energy

[a] Dr. M. Pagliaro

Istituto per lo Studio dei Materiali Nanostrutturati, CNR

via U. La Malfa 153

90146 Palermo (Italy)

E-mail: mario.pagliaro@cnr.it

[b] Dr. F. Meneguzzo

Istituto di Biometeorologia, CNR

via Madonna del Piano 10

50019 Sesto Fiorentino (Italy)

E-mail: francesco.meneguzzo@cnr.it

[c] M. Pecoraino

via C. Giacquinto 14

90135 Palermo (Italy) consumption: more than $40 \%$ in European Union (EU) countries, ${ }^{[2]}$ and a similar percentage in China, where building energy consumption has increased at $7 \%$ annual rate since 2001. ${ }^{[3]}$

Countries in Europe generally have limited or even no fossil fuel resources, with oil production from the oil and gas reserves in the North Sea having decreased at fast pace since 1999 (for instance, the United Kingdom's offshore oil production went from 398 million barrels in 1999 to 220 million barrels in 2007). ${ }^{[4]}$

In this context, aiming at saving oil and natural gas considered strategic for industry and transport sectors, it is perhaps not surprising that starting in the early 2000s the EU drafted increasingly tight legislation to promote energy efficiency in buildings along with the use of renewable energy. Since 2002 first, and even more strictly since 2010, an Energy Performance of Buildings Directive defines minimum criteria for the energy performance of new and refurbished buildings

The 2010 EPBD, for instance, requires all new buildings to be nearly zero-energy by the end of 2020; and by 2018 for all new public buildings. ${ }^{[5]}$

New legislation resulted in a decrease in the consumption of energy by the residential sector from about 318 MTOE in 2000 to 287 in $2014 ;{ }^{[6]}$ though half of the efficiency gains achieved through technological innovation in the household sector have been offset by an increasing number of electrical appliances and larger homes. ${ }^{[2]}$

Furthermore, action must be taken to improve the situation of the existing building stock, since about $75 \%$ of buildings are truly energy inefficient and, depending on the country, only $0.4-1.2 \%$ of the stock is renovated each year. ${ }^{[7]}$

Alone, the conflict between increasing specific dwelling consumption and increasing energy efficiency of buildings observed in the EU countries shows that energy efficiency alone is not enough. The generation and use of renewable energy is of similar paramount importance.

The solar city concept, namely the use of surfaces in the entire urban built environment to generate electricity via solar photovoltaic (PV) modules, ${ }^{[8]}$ is being actively explored in the context of the energy transition to renewable energy. Solar city possibilities, for example, were lately considered for cities as large and as important as Amsterdam, London, Munich, New York, Seoul, and Tokyo. ${ }^{[9]}$ 
When dealing with historic cities large-scale adoption of solar energy requires systematic architectural integration of the solar energy technology to combine historic preservation with efficient generation of renewable energy. Preserving the architectural integrity and historic value of old buildings, indeed, historic preservation is as important as the generation of clean energy.

Hosting the largest historic heritage of the world, ${ }^{[10]}$ and with good to excellent solar irradiance levels, ${ }^{[11]}$ Italy has pioneered the development of building integrated photovoltaics (BIPV), a multifunctional technology that unifies the photovoltaic module with the overall building outer surface providing the building with several other functions. ${ }^{[12]}$ For example, an Italian-German research and demonstration project (PVAccept) funded by the European Commission between 2001 and 2004 developed different marketable PV solar modules of innovative design for their integration into old buildings, historical sites, the urban space and landscapes. ${ }^{[13]}$

Awarded the 2008 European Solar Prize for the category "solar architecture", ${ }^{14]}$ Rome hosts on the rooftop of the "Paul VI" Audience Hall in the Vatican City an elegant PV array comprised of 2,394 ad-hoc modules in crystalline silicon of 220 kilowatt peak $(\mathrm{kWp})$ nominal power (Figure 1).

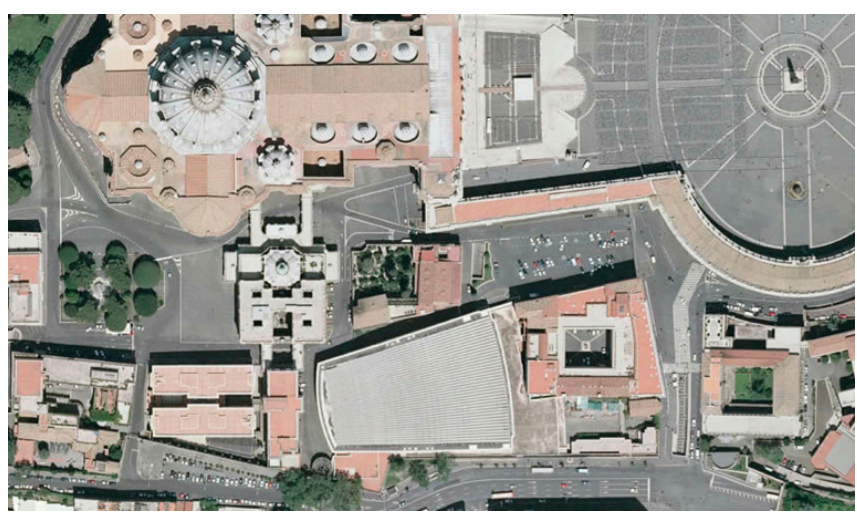

Figure 1. The photovoltaic array on the rooftop of 'Paul VI' Audience Hall in the Vatican City is visible on the bottom part of the photograph.

Shortly afterwards, de Santoli, who designed the system, has explored the integration of new energy technologies for sustainability in Rome, from the analysis of energy savings achievable through PV systems on school roofs, ${ }^{[15]}$ through energy savings achievable via the retrofitting of public housing dwellings from the 1940's in an historic neighborhood. ${ }^{[16]}$

Yet, still today neither the city of Rome nor Italy's central or regional governments have published guidelines with the criteria for incorporating solar PV and solar thermal (ST) technologies in the built environment. As a result, the use of solar modules and thermal collectors in the historic center of cities like Rome, Florence, Venice, Catania and Naples is practically nihil. For comparison, in order "to find a proper balance between technical and aesthetic requirements", several Swiss Cantons have guidelines for the integration of solar technologies in the building environment. ${ }^{[17]}$
On the other hand, Italy's new energy strategy for the period 2020-2030 (Strategia Energetica Nazionale - SEN) has identified PV as one of the best options for increasing the share of renewable energy in the country, ${ }^{[18]}$ and to eliminate coal power production by 2025 by increasing the share of renewable energy sources to $27 \%$ in 2030 . In detail, power production from PV is expected to increase from 21.104 TWh in 2016 to 72 TWh by 2030: an energy production target which requires new solar installations to exceed $3 \mathrm{GW}$ per year.

For comparison, since the end of the Feed-in-Tariff (FiT) incentives in mid 2012, Italy which had gone from 3 to $17 \mathrm{GW}$ installed PV capacity in just 2 years, has installed only $2.7 \mathrm{GW}$ while Australia, with a population about $35 \%$ of Italy's, has over the same five years installed around $6 \mathrm{GW}$ of rooftop PV. ${ }^{[19]}$

Referring to Rome as the city with the world's largest historic heritage, this paper identifies selected technology solutions and critical policy and educational initiatives to effectively achieve within the next decade (2018-2027) the needed widespread uptake of decentralized solar energy systems in the built environment on a truly global scale.

Mario Pagliaro is a chemistry and energy scholar based in Sicily. His group's research and educational achievements in chemistry, solar energy and the bioeconomy are reported in over 200 frequently cited research papers and 21 books. All work is developed in co-operation with leading researchers based in over 20 countries. Dr Pagliaro ranks amongst Italy's most cited scientists in nanotechnology and materials chemistry. In recognition of his "significant contributions to the chemical sciences" in 2014 he was designed Fellow of the Royal Society of Chemistry.

A physicist at the Institute of Biometeorology of Italy's Research Council in Florence, Francesco Meneguzzo coordinates a research group active in numerous fields from energy to the bioeconomy. His recent achievements include the development of an entirely new brewing process based on hydrodynamic cavitation technology which has been called by the MIT Technology Review the "technology which is about to revolutionize beer-making". Between 1996 and 2002, as a weather forecaster, he has established Tuscany's Regional Met Service, later to become the well-known LAMMA weather forecast centre. He has helped drafting the FiT law that made Italy in less than 3 years one of the world's leading countries in terms of installed PV power. 


\section{Solar Building Integration}

Integrating the PV modules in the urban context, a significant fraction of the energy consumed within said environment is produced there where it is needed, cutting the costs of energy transport and diminishing the load on the grid: thereby enabling the distributed generation condition and its many economic and environmental advantages; ${ }^{[20]}$ especially when supported by smart grids and completed by more energy efficient buildings. ${ }^{[21]}$

Integrating the photovoltaic functionality in Rome's building is a remarkable energy option. Figure 1 shows an accurate estimation of the PV output electricity obtained with state of the art software (pvPlanner, Solargis) relying on one of the world's most accurate solar database. ${ }^{[22]}$

In Rome (lat/lon: $41.9028^{\circ} / 12.4964^{\circ}$ ) a $1 \mathrm{kWp}$ PV system with modules in crystalline silicon has optimal orientation (azimuth) to South with an inclination of $34^{\circ}$. Under this conditions, taking into account 7 different energy losses yielding an average $78.3 \%$ performance ratio, the PV array will generate $1456 \mathrm{kWh}$ (Figure 1). ${ }^{[23]}$

The same PV array in December produces an amount of energy which is $49,1 \%$ of the amount generated in the most productive month of the year (July, Table 2), meaning that in Rome photovoltaic generation can yield a significant contribution to the energy needs even during the winter months.

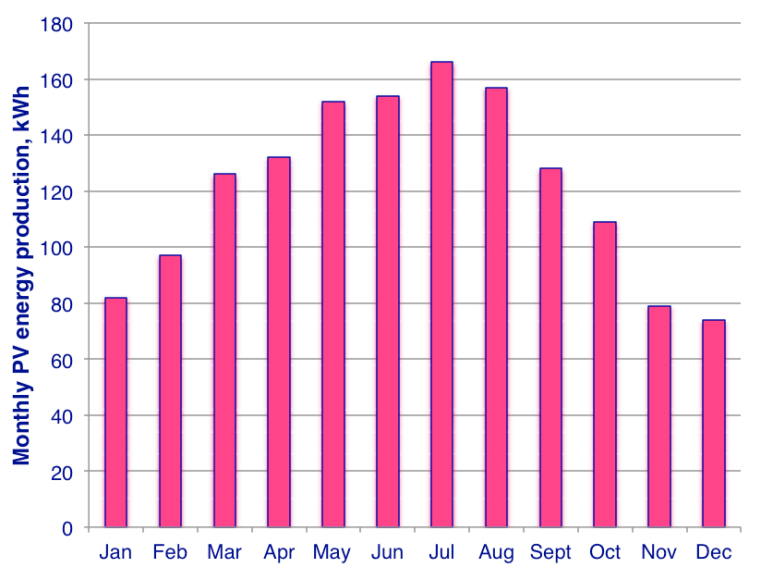

Figure 2. Monthly PV energy production of a $1 \mathrm{kWp}$ array with optimal South orientation and $34^{\circ}$ tilt angle [Source: pvPlanner, Solargis].

It is relevant that in Rome, where existing roofs in the historic center generally share a common tilt of $14^{\circ},{ }^{[24]}$ even a flat (horizontal) PV array will receive a global irradiance that is $86.3 \%$ of the ideal amount of sun radiation with optimal $\left(34^{\circ}\right)$ tilt. ${ }^{[23]}$

Assuming to integrate the PV functionality on the surface of all Rome's residential building rooftops $\left(22\right.$ million $\left.\mathrm{m}^{2}\right),{ }^{[25]}$ even previous generation PV modules affording $1 \mathrm{~kW}$ for each $10 \mathrm{~m}^{2}$ would generate about 3.2 TWh of clean electricity annually there where this energy is mostly needed.
In most cases in which Italy's (and Sicily's) Superintendences of Cultural Heritage denied homeowners permission to install solar panels, justification was mostly based on the exigence "to keep unaltered the chromatic, morphologic and material features of rooftops".

In Italy, rooftops of the typical dwellings of historic cities and sites are realized with tiles in terracotta (earthenware), a material of exceptional properties whose use in Italy dates back to the early days of ancient Rome. Progress in the development of solar energy systems, however, has solved the dilemma between clean energy and historic preservation, without having to compromise. Bent and flat solar tiles in terraccotta address exactly the objections raised by the Superintendences of Cultural Heritage: they retain the morphological, chromatic and material characteristics of conventional earthenware roofs, while retaining all other services provided by earthenware tiles including thermal flywheel and waterproofing properties, prolonged resistance to extreme weather conditions and microbial attack.

In this sense, solar tiles in terracotta are integrated and truly multifunctional BIPV systems using solar irradiance to provide energy while also providing the building with many other functions.

Table 1. Monthly energy outuput and performance ration from a $1 \mathrm{kWp} \mathrm{PV}$ array in Rome with optimal tilt [Source: pvPlanner, Solargis].

\begin{tabular}{lllll}
\hline Month & $E_{m}(\mathrm{kWh})^{\mathrm{ia}]}$ & $E_{\mathrm{d}}(\mathrm{kWh})^{[\mathrm{b}]}$ & $E_{\text {share }}(\%)^{[\mathrm{cc}]}$ & $\mathrm{PR}^{[\mathrm{d}]}$ \\
\hline Jan & 82 & 2.63 & 5.6 & 83.4 \\
Feb & 97 & 3.46 & 6.7 & 82.5 \\
Mar & 126 & 4.08 & 8.7 & 81 \\
Apr & 132 & 4.40 & 9.1 & 79.6 \\
May & 152 & 4.89 & 10.4 & 77.4 \\
Jun & 154 & 5.14 & 10.6 & 75.8 \\
Jul & 166 & 5.37 & 11.4 & 74.6 \\
Aug & 157 & 5.07 & 10.8 & 74.8 \\
Sept & 128 & 4.26 & 8.8 & 77 \\
Oct & 109 & 3.52 & 7.5 & 79.4 \\
Nov & 79 & 2.63 & 5.4 & 81.4 \\
Dec & 74 & 2.38 & 5.1 & 83.1 \\
TOTAL & 1456 & 3.99 & 100 & 78.3 \\
\hline
\end{tabular}

[a] $\mathrm{E}_{\mathrm{m}}=\mathrm{kWh}$ produced per month; [b] $\mathrm{E}_{\mathrm{d}}=\mathrm{kWh}$ produced per day; [c] $\mathrm{E}_{\text {share }}$ $=\%$ of the yearly energy production; [d] PR = performance ratio. 
Even if seen from above, the result of the replacement of conventional tiles with the PV tiles in terracotta is an eyecatching roof in which the solar cells are barely visible (Figure 3 ).

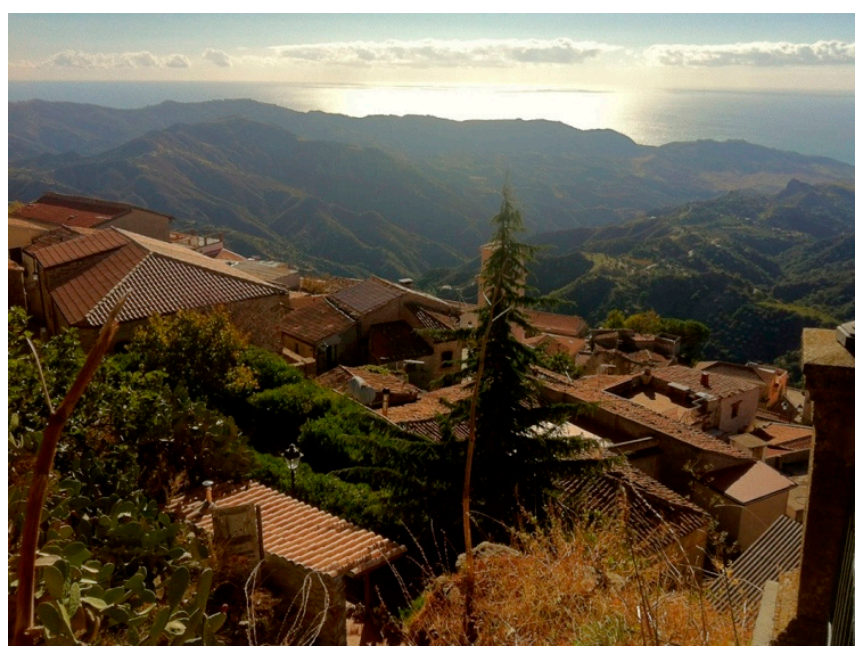

Figure 3. The $2 \mathrm{kWp}$ rooftop in solar PV bent tiles at the centre of this picture taken in Melito Porto Salvo, Calabria, Italy, is barely visible. [Photo courtesy of Industrie Cotto Possagno].

In the 2017 Swiss guide to BIPV one can read that "solar tiles traditionally have a small market share due to the high cost levels, but recently gained significant marketing exposure due to their ability to replace the traditional tiling in a roof'. [26]

Such "significant marketing exposure" has been due to the dramatic fall in price of the solar cells integrated on each tile. The price decrease has gone along with accelerated technology progress which has concerned each component of solar PV systems. The old solar cells in polycrystalline silicon, iridiscent and coloured in blue, coated with glass bearing no antireflective coating and with the silver contacts on the front of each cell clearly visible, have been replaced by more efficient cells in monocrystalline silicon coloured in black treated with an antireflective coating (Figure 4).

Progress encompasses also the use of a single bypass diode per tile, with the result to dramatically improve the shading tolerance when compared to conventional PV modules. In general, in fact, PV modules are sensitive to the current mismatches introduced by shadows (trees, chimneys, aerials, leaves etc.) because of their series architecture of electrical interconnections. ${ }^{[27]}$

Today's state of the art 60-cell modules use 2 or 3 diodes in the junction box to stabilize energy yield against shading. State of the art PV tiles in terracotta (Table 2) are each equipped with a single bypass diode.

Electricity generation is also enhanced, compared to conventional modules, by the natural ventilation ensured by a channel left between the solar cells and the bent tile which lowers the temperature on the back of the solar cells, improving the electricity output during the hottest summer days.
Table 2. Typical characteristics of a current solar bent tile produced in Italy.

\begin{tabular}{lllll}
\hline Technology ${ }^{[a]}$ & Power (W) & Size $(\mathrm{mm})$ & $\begin{array}{l}\text { Power } \\
\text { density }\end{array}$ & $\begin{array}{l}\text { Price } \\
\left(\mathrm{CHF} / \mathrm{m}^{2}\right)\end{array}$ \\
\hline $\mathrm{mc}-\mathrm{Si}$ & 4 & $\begin{array}{l}335 \times 88 \times 4 \\
(\text { Lxwxt })\end{array}$ & $60\left(\mathrm{~W} / \mathrm{m}^{2}\right)$ & $\begin{array}{l}215(\mathrm{excl} . \\
\text { VAT })\end{array}$ \\
\hline
\end{tabular}

[a] SUPSI/SEAC, Building Integrated Photovoltaics: Product overview for solar building skins, Status Report 2017.
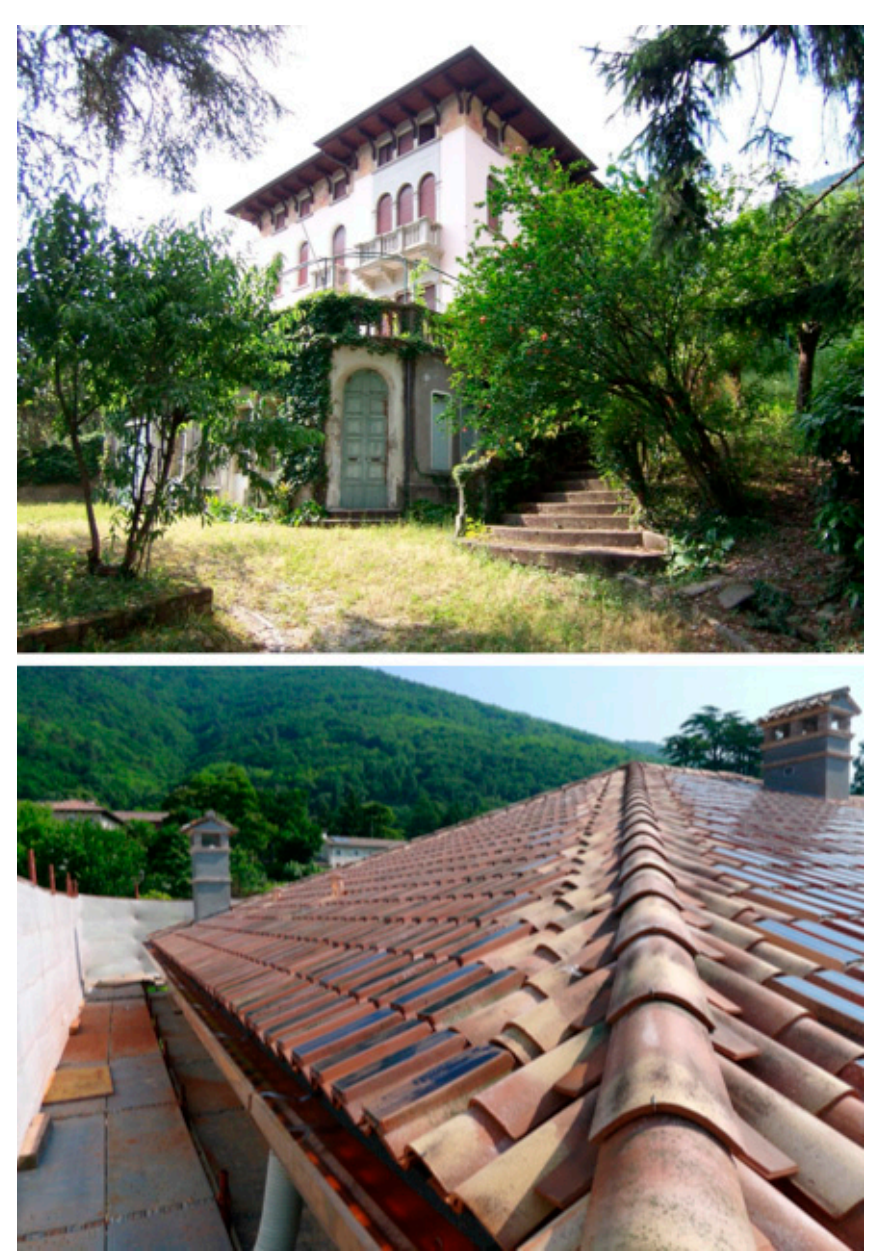

Figure 4. A $6 \mathrm{kWp}$ solar array in PV bent tiles comprising the rooftop of an early 1900s villa in Valdobbiadene, Italy. [Photo courtesy of Industrie Cotto Possagno].

Finally, contributing to lower installation costs, the electrical connection among the tiles is quick and easy relying on a simple snap-on multi-contact fixture system, whereas the absence of mounting systems and fixing rods for laying conventional solar modules prevents potential rainwater infiltration and the formation of thermal bridges.

Generally developed by existing tile and brick manufacturers, often in collaboration with solar energy technologists and designers, different PV tiles are already available on the marketplace. One such tile, for instance, embodies 12 solar cells 
in polycrystalline silicon offering a $13.5 \mathrm{~kW}$ nominal power which, taking into account the tile size $(478 \times 428 \times 90 \mathrm{~mm})$, translates into a nominal power density of ca. $91 \mathrm{~W} / \mathrm{m}^{2}$ requiring only 74 solar tiles to achieve $1 \mathrm{~kW}$ of nominal power. ${ }^{[28]}$

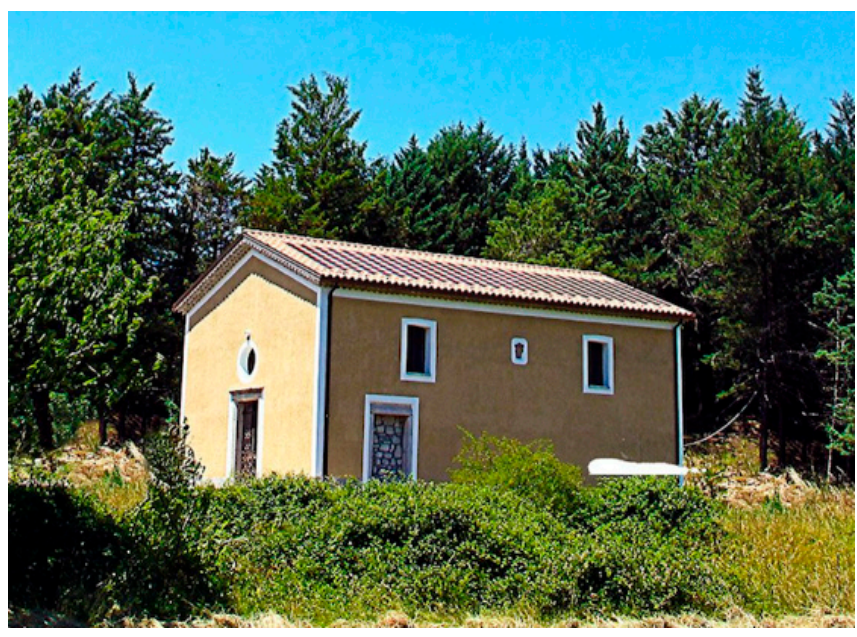

Figure 5. A $3.024 \mathrm{kWp}$ solar array in PV tiles comprising the rooftop of Cappella dell'Incoronata, Cassano Irpino, Italy. [Photo courtesy of FotoSun].

In general, the geometry and conformation of the tiles is studied in order to avoid shading and obstruction (maximum ventilation of the highly exposed photovoltaic surface). Again, the outcome of the solar tile integration is as elegant (Figure 5) as energy effective.

The replacement of conventional tiles with solar PV tiles is even more important when considering that new generation Marseille and Portuguese roof tiles, which cover more than $60 \%$ of pitched roofs in Europe and are ubiquitous in Mediterranean countries and islands, will prevent overheating of the building indoor environment even to a larger extent. ${ }^{[29]}$

In further detail, a significant reduction of energy consumption for cooling in Mediterranean climates is expected when compared to conventional rooftops in terracotta thanks to the slightly modified shape ensuring higher air permeability through the overlap of the tiles and improved under-tile ventilation independent of wind direction (newly designed inlet and outlet channels let the air flow horizontally as well as vertically).

The first results of the tests with real roofs in two buildings located in Israel close to the Negev desert, one equipped with conventional Portuguese tiles and the other with its evolution, show an air velocity achieved by the new roof which is 2 times higher than that of the standard roof. ${ }^{[30]}$

Leaving the historic city center, conventional buildings are ready to be functionalized with solar technology. From flexible through semitrasparent and bifacial modules, numerous BIPV solutions are commercially available to functionalized buildings of all size and end use. ${ }^{[31]}$
In this respect, a major advance towards the full integration of solar PV and solar ST technologies in the built environment has been the development of the Kromatix nanoscale coating technology eventually providing solar collectors with colors in a wide range (including blue, brown, green and terracotta) due to light interference on the thin film.

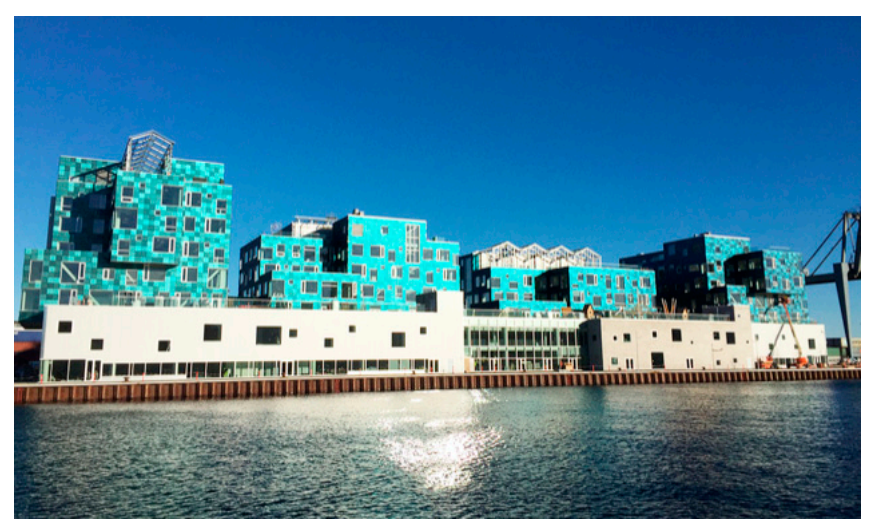

Figure 6. The facade of Copenhagen International School comprised of solar modules coloured in sea green. [Photograph of Philippe Vollichard, EFPL].

The loss of collector's energy performance is $<10 \%$ (for instance, by replacing the glass of a $300 \mathrm{Wp}$ PV module with satinated glass with a thin film interference filter, the nominal power becomes about $280 \mathrm{Wp}$ for the blue color and about $285 \mathrm{Wp}$ for the orange). ${ }^{[32]}$

Further enhancing the overall aesthetics, the colored glass has a opaque finish making invisible the inner parts of the solar collectors, thereby overcoming all aesthetic challenges of conventional solar technology opening the route to full exploitation of all building surfaces (Figure 6).

Another major advance that will find widespread utilization in the world's cities is the concomitant functionalization of existing rooftops with PV modules and vegetation (Figure 7). While generating clean electricity, the resulting green solar roof provides numerous additional benefits, reducing the effects of urban heat-island effect, the rainwater run-off and improving the quality of the city's air.

Furthermore, provided that adequate vegetation such as hairy plants is first selected and the properly managed to avoid shading and proliferation of invasive species, electricity generation is even enhanced thanks to the soil evapotranspiration which, in comparison to a conventional rooftop in gravel or bitumen, keeps the rooftop at a considerably lower temperature, cooling the PV modules and improving the energy production in summer months. ${ }^{[33]}$

Finally, the PV modules on the green roof successfully support biodiversity providing on their back an excellent microhabitat for pollinators, including honeybees, numerous insects and birds. 


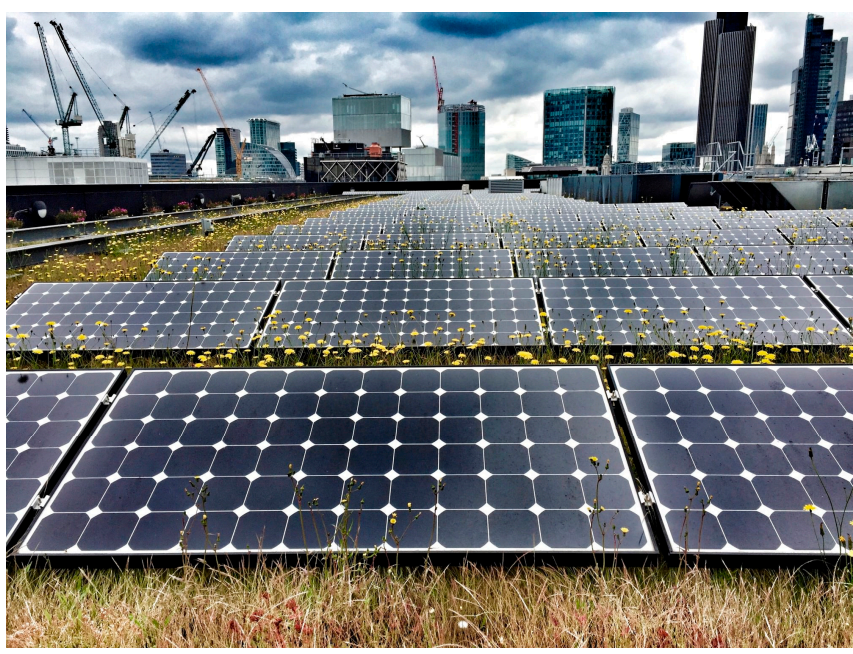

Figure 7. A biosolar roof in London. [Photograph of Livingroofs.org, United Kingdom].

Reporting lately that systematic use of the biosolar roof across the world is still scarce, ${ }^{[34]}$ Baumann, a pioneering scholar in the field, ascribed it to the lack of proper education with several cases in which the selected biosolar roof vegetation was not optimal, and positioning and orientating of the PV modules, requiring a mounting system optimized for green roofs, was not correct.

A similar trend towards building integration is concomitantly taking place for the solar thermal technology. For decades, for example, natural circulation solar thermal systems with their cumbersome storage tanks and flat glass collectors, though highly effective in providing domestic hot water, have been the icones of solar energy technology poor aesthetics.

Today's ever more cost-effective and efficient solar thermal systems are elegant and building-integrated, leaving the roof available for integration of PV, with façade-integrated collectors providing numerous added benefits to the building. ${ }^{[35]}$

Figure 8, for example, shows the outcome of integrating a solar air collector in a building in Palermo, Sicily. The collector is barely visible, but the household has halved the natural gas consumption while accessing the unique health benefits of the solar ventilation technology. ${ }^{[6]}$

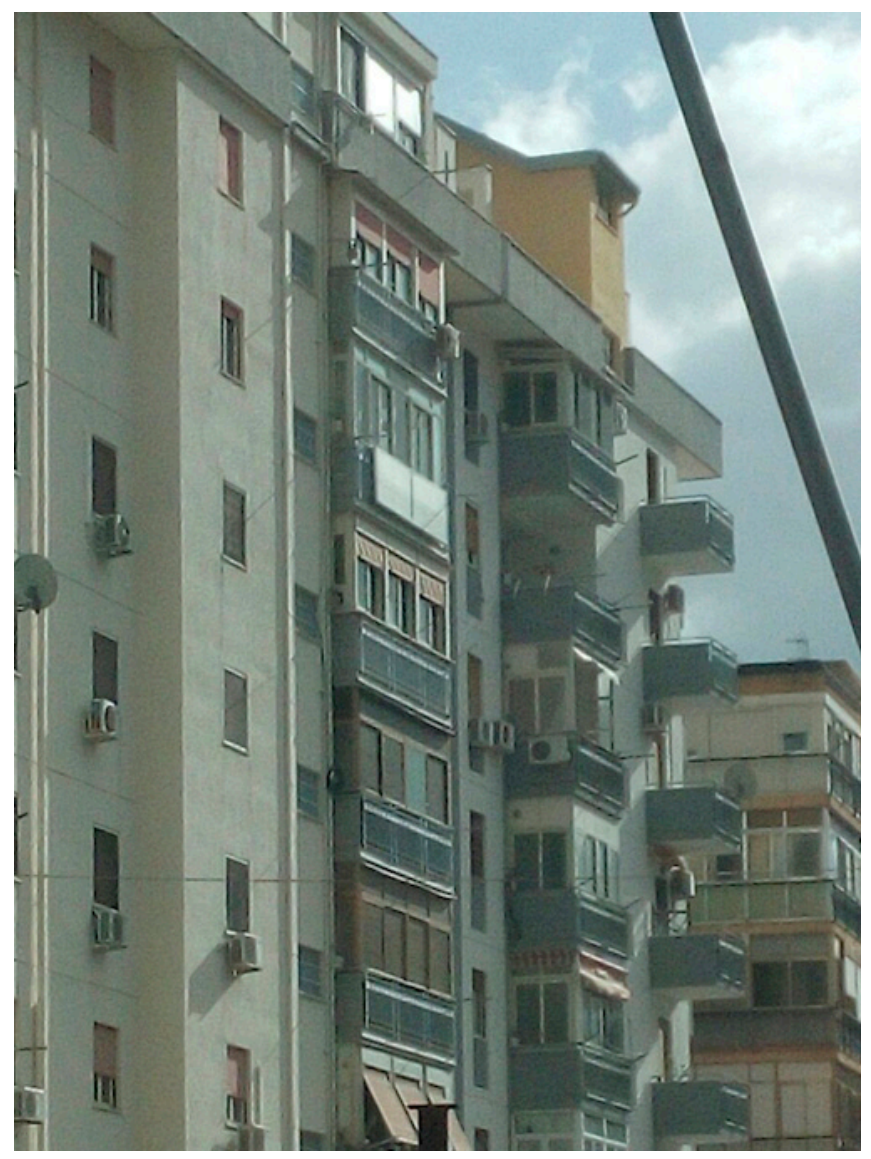

Figure 8. Custom-size solar air thermal collector integrated in the balcony of a residential building in Palermo, Sicily. [Photograph of Mario Pecoraino, reproduced with kind permission].

\section{Renewable energy: A Strategic Insight}

The economically sound but politically difficult renewable energy, to use Sovacool's language,,$^{[37]}$ has won its battle in terms of technical and economic feasibility.

Even without internalizing the costly environmental externalities of conventional electricity generation (i.e. taxing pollutant emissions), it has been enough to concomitantly deploy FiT policies and grant priority access to the grid to renewable electricity to literally revolutionize the electricity market in all those countries with a significant renewable electricity production, including Italy. ${ }^{[38]}$

In Germany, the world's fourth largest economy, electricity in 2017 traded at wholesale price of $€ 33,14 / \mathrm{MWh}$ with renewable energy production overcoming the 200 TWh for the first time, and 104 hours of negative prices in the year. ${ }^{[39]}$

Currently, German electricity consumers are paying high electricity bills (ca. $€ 0.22 / \mathrm{kWh}$ ) due to temporary surcharges financing the FiT incentives, and yet the wholesale price of electricity in 2017 was $€ 0.033 / \mathrm{kWh}$, in a steep decrease parallel to the dramatic increase of renewable energy generation (Figure 9). 
One might therefore ask what would happen to the economy of competing countries when, in about ten years from now, electricity bills in Germany will no longer comprise FiT surcharge and German companies and consumers will access electricity at unprecedented low cost.

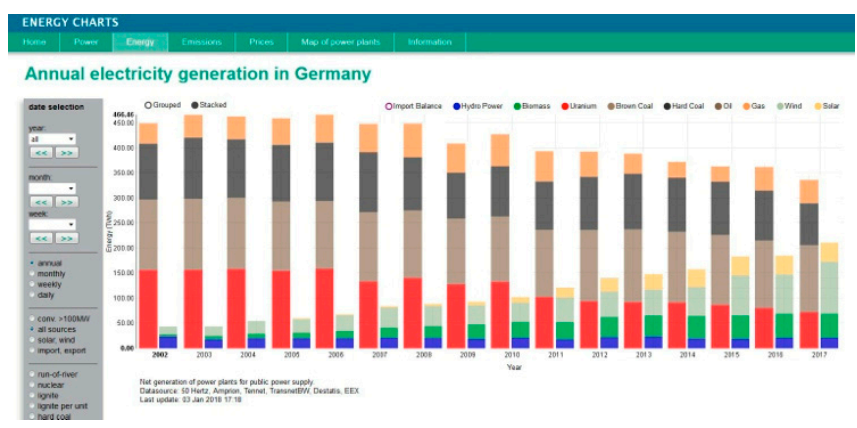

Figure 9. The growth of renewable energies and the decline in conventional generation from 2002 to 2017 in Germany [Graph created by Dr Oliver Blanck, from Energy-Charts.de].

The key concept is therefore as simple as challenging: countries need to seriously act now to vastly increase the amount of renewable energy generated, which obviously includes distributed generation in buildings.

The process is eventually taking place, though it needs to accelerate. In 2017, for example, the amount of installed PV power in the world approached the $100 \mathrm{GW}$ threshold with $>50$ GW installed only in China, with the PV industry entering a new phase in which annual delivery of $>100 \mathrm{GW}$ will become the norm. ${ }^{[40]}$

A concomitant $60 \mathrm{GW}$ increase in the amount of wind power installed in 2017 brought the total to cross the $530 \mathrm{GW}$ threshold Wind energy generation already covered $3.7 \%$ of the world's electricity demand in 2015 , when the global power installed was $432 \mathrm{GW} .{ }^{[41]}$ For comparison, the world's 440 nuclear reactors in 2015 covered $11 \%$ of the world's electricity yearly demand, with an energy output of slightly less than $2500 \mathrm{TWh} .{ }^{[42]}$

\section{Perspective and Recommendations}

The grand energy objective for the built environment is clear: we need to improve the energy efficiency and convert buildings from consumers of fossil-derived energy to users and generators of renewable energy.

It is therefore necessary to undertake a global effort using economically affordable solar technology to functionalize the existing building stock. About half of the first $300 \mathrm{GW}$ of globally installed PV power until 2016 was comprised of distributed rooftop $\mathrm{PV} ;{ }^{[43]}$ and yet less than $5 \%$ of buildings globally are functionalized with PV modules.

This process, which for decades was impeded by the high cost and poor aesthetics of the two main solar energy technologies (solar photovoltaics and solar photothermal), is now technically and economically possible thanks to remarkable technical progress and dramatically improved economics.

China's massive investments in solar cell production plants and solar energy R\&D have been successful, bringing the price of PV cells and modules to historic lows $(<\$ 0.4 / \mathrm{W})$, and annual global demand for solar power to $100 \mathrm{GW}$ for the first time ever in 2017. ${ }^{[44]}$

Today's main difficulty with promoting renewable energy decentralized generation is mostly due to the need to locally involve communities, and therefore to focus on the vastly neglected social and cultural dimensions of this effort. ${ }^{[45]}$ For example, local social cooperation is needed to optimize the contribution of distributed generation and distributed storage via cooperation of different households to insert the renewable energy in a jointly owned microgrid with mutual delivery. ${ }^{[46]}$

Hence, rather than focusing only on the technical and economic dimension of the transition to renewable energy, policy makers should creatively develop new policies that take into account also the social and cultural nature of the energy transition; whereas proactive action is required from all the transition stakeholders.

\subsection{New legislation supporting distributed generation}

National governments are required to deploy legislation supporting distributed generation via preferential access to the grid and the development of microgrids powered by renewable energy. Regional governments are called to draft new legislation aimed at promoting uptake of decentralized energy generation, publishing updated guidelines for the integration of solar technologies in both conventional and historic buildings. Cities, on their turn, are required to update building codes inserting measures aimed at supporting adoption of building-integrated solar technology, from green solar rooftops to rooftops using solar tiles.

\subsection{Community involvement and communication}

Solar energy companies, environmental activists, educational centres, regional governments and cities must unite forces and deploy effective communication strategies to reach out citizens and make them aware of how advantageous and useful for them and for the community is the adoption of decentralized solar energy.

This will include $i$ ) advertising on mass media, ii) highly usable and interactive websites with practical information concerning solar technology integration in buildings, and iii) creating contact points and information centres.

Beyond the community, communication and involvement activities will be aimed also at experts in other fields who are not acquainted with solar energy and energy efficiency technologies: for example to foster collaboration among professionals in both historic preservation and solar energy to receive appropriate support and guidance. ${ }^{[47]}$ 


\subsection{Reshaping education}

National and regional policy makers are recommended to establish new research and educational competence centres to properly educate professionals providing them with the updated knowledge and skills necessary to promote building-integrated solar technology as a reliable and cost competitive option to produce electricity and heat for all sort of buildings. ${ }^{[48]}$

In the age of nearly-zero energy buildings, this knowledge is still limited. For example, scholars in a top literacy country such as Hungary in 2012 found that the "lack of knowledge of buildingintegrated solar technology among architects" was "the main problem requiring new education... to show them how they can ...create attractive solar architecture". ${ }^{[49]}$

In the path to achieve these remarkably important goals, we can borrow concepts and ideas from faraway domains, for example from the history of medicine.

With a community of 13,000 well trained physicians scattered throughout the island responsible for between 1,000 and 1,500 patients, Cuba, an island with 11.2 million inhabitants and a modest gross domestic product, has brought life expectancy from 70.04 in 1970 to 78.7 years in 2016; and infant mortality rate from 37.3 in 1959 to 4.3 per 1000 live births in 2016, a rate equivalent to that of Australia lower to that of the US (5.8). ${ }^{[50]}$

The whole system is based on 13 medical schools where all the country's physicians are trained. Actually, these schools have trained a surplus of physicians so that the country sends 25,000 physicians abroad annually to provide care in developing countries. ${ }^{[51]}$

A similarly serious and committed policy effort can, and should, be deployed with solar energy technologies to accelerate the energy transition as required by the urgency of the oil, population and wealth dynamics. ${ }^{[1]}$

Countries are called to establish new solar energy (and bioeconomy) research and educational institutes, where to shape the professionals needed to guide the energy transition.

This is, for example, what Germany did in 1981 by establishing the Fraunhofer Institute of Solar Energy. Interestingly, China National Renewable Energy Centre (CNREC) in 2012 was an outcome of the Sino-Danish Renewable Energy Development Programme, a joint effort between China and Denmark aimed at developing "the capability of the authorities to manage the rapid development of renewable energy in China".

A path similar to that pursued by the recently established Swiss BIPV Competence Centre and the Solar Energy Application Centre in the Netherlands which cooperate for example in producing an annual report on BIPV products.

With the transition to the solar economy now fully unfolding, we argue in conclusion, within a few years all world's countries will operate similar solar energy and bioeconomy institutes. ${ }^{[52]}$.

\section{Acknowledgements}

Thanks to Dr Marcel Suri, Solargis (Bratislava, Slovakia), for providing access to pvPlanner software. We thank Dr Georgios Martinopoulos, International Hellenic University, Thermi, Greece, and Architect Ciro Lomonte, Rome and Palermo, Itly, for helpful correspondence.

[1] F. Meneguzzo, R. Ciriminna, L. Albanese, M. Pagliaro, The energypopulation conundrum and its possible solution, arXiv 1610.07298 [physics.soc-ph].

[2] European Environment Agency, Progress on energy efficiency in Europe, ENER 037, 21 November 2016, https://www.eea.europa.eu/data-and-maps/indicators/progress-onenergy-efficiency-in-europe-2/assessment-2 (last time accessed: 10 January 2018).

[3] Y. Zhang, C.-Q. He, B.-J. Tang Y.-M. Wei, China's energy consumption in the building sector: A life cycle approach, Energ. Buildings 2015, 94, 240-251.

[4] Office for National Statistics, UK National Accounts, The Blue Book: 2011, section 13.1.

[5] The European Parliament and the Council of the European Union, Directive 2010/31/EU of the European Parliament and of the Council of 19 May 2010 on the energy performance of buildings (recast), Official Journal of the European Union L 153/13, 18 June 2010.

[6] ODYSSEE-MURE, Synthesis: Energy Efficiency Trends and Policies in the EU An Analysis Based on the ODYSSEE and MURE Databases September 2015, Available at: http://www.odysseemure.eu/publications/br/synthesis-energy-efficiency-trends-policies.pdf (Accessed: 10 January 2018).

[7] European Commission, "Commission welcomes agreement on energy performance of buildings", 20 December 2017 https://ec.europa.eu/energy/en/news/commission-welcomesagreement-energy-performance-buildings (Accessed: 10 January 2018).

[8] H. Scheer, Solar City: Reconnecting Energy Generation and Use to the Technical and Social Logic of Solar Energy In Urban Energy Transition: From Fossil Fuels to Renewable Power, P. Droege (Ed.), Elsevier, Amsterdam: 2008; pp. 17-26.

[9] J. Byrne, J Taminiau, K. N. Kim, J. Lee, J. Seo, Multivariate analysis of solar city economics: impact of energy prices, policy, finance, and cost on urban photovoltaic power plant implementation, WIREs Energy Environ. 2017, 6, e241.

[10] For example, as of 2017 Italy has 53 sites (48 cultural and 5 natural) in the UNESCO World Heritage List, more than any other country: http://whc.unesco.org/en/statesparties/it (Accessed: 10 January 2018).

[11] A. Andretta, B. Bartoli, B. Coluzzi, V. Cuomo, M. Francesca, C. Serio, Global solar radiation estimation from relative sunshine hours in Italy, $\mathrm{J}$. Appl. Meteor. 1982, 21, 1377-1384.

[12] M. Pagliaro, R. Ciriminna, G. Palmisano, BIPV: merging the photovoltaic with the construction industry, Prog. Photovoltaics: Res. Appl. 2010, 18, 61-72.

[13] PVACCEPT, 2001-2004. See at the URL: www.pvaccept.de/pvaccept/eng/index.htm (Accessed: 10 January 2018).

[14] Eurosolar, Laureates of the European Solar Prize 2008, http://eurosolaritalia.org/documenti/news/Laureates_European_Solar_P rize_2008-2.pdf (Accessed: 10 January 2018).

[15] L. de Santoli, G. Moncada Lo Giudice, F. Fraticelli, F. Fornari, C. Calice Analysis on Energy Saving Achievable Through Solar Photovoltaic Systems on School Roofs: the Case of the City of Rome, J. Energy Power Engineer. 2014, 8, 448-452.

[16] L. de Santoli, F. Mancini, B. Nastasi, S. Ridolfi, Energy retrofitting of dwellings from the 40's in Borgata Trullo-Rome, Energy Procedia 2017, 133, 281-289

[17] The guidelines for 7 difference Cantons can be downloaded at the URL: www.bipv.ch/index.php/en/guidelines (Accessed: 10 January 2018). 
[18] Ministero dello Sviluppo Economico, Italy's National Energy Strategy 2017 ,

www.sviluppoeconomico.gov.it/images/stories/documenti/brochure_eng _sen.pdf (Accessed: 10 January 2018).

[19] T. Kenning, "Australia surpasses $6.29 \mathrm{GW}$ of rooftop solar", pv-tech.org, 8 January 2018. See at the URL: www.pv-tech.org/news/australiasurpasses-6.29gw-of-rooftop-solar (Accessed: 10 January 2018).

[20] Distributed Generation and its Implications for the Utility Industry, F. P. Sioshansi (Ed.), Academic Press, New York: 2014.

[21] M. Amado, F. Poggi, Solar energy integration in urban planning: GUUD model, Energy Procedia 2014, 50, 277-284.

[22] $A \pm 3.1 \%$ bias based on quality ground measurements in more than 200 sites across all type of climates. Solargis, "Validation and uncertainty of solar resource data", https://solargis.com/support/accuracy-andcomparisons/overview (Accessed: 10 January 2018).

[23] pvPlanner, Stima del rendimento di una centrale fotovoltaica, Rapporto numero: PV-2-1801-495, 3 January 2018.

[24] Professor E. M. Mazzola, University of Notre Dame, School of Architecture, Rome, personal communication, 3 January 2018.

[25] Professor L. de Santoli, University of Rome La Sapienza, personal communication, 8 January 2018.

[26] SUPSI/SEAC, Building Integrated Photovoltaics: Product overview for solar building skins, Status Report 2017, www.bipv.ch/images/Report\%202017_SUPSI_SEAC_BIPV.pdf (Accessed: 10 January 2018).

[27] B. B. Pannebakker, A. C. de Waal, W. G. J. H. M. van Sark Photovoltaics in the shade: one bypass diode per solar cell revisited. Prog. Photovoltaics Res. Appl. 2017, 25, 836-849.

[28] The photovoltaic tile TILE DUAL PV. FBM Furnaces Briziarelli Marsciano SpA.

[29] The tiles are the outcome of the applied Life HERO Tile research project funded by the EU, see at the URL: www.lifeherotile.eu (Accessed: 10 January 2018).

[30] M. Bottarelli, M. Bortoloni, G. Dino, Experimental analysis of an innovative tile covering for ventilated pitched roofs, International Journal of Low-Carbon Technologies 2017, 1-9.

[31] A. K. Shukla, K. Sudhakar, P. Baredar, Recent advancement in BIPV product technologies: A review, Energ. Buildings 2017, 140, 188-195.

[32] N. Jolissaint, R. Hanbali, J-C- Hadorne, C. Schüler, Colored solar façades for buildings, Energy Procedia 2017, 122, 175-180.

[33] C. Catalano, N. Baumann, Biosolar Roofs: A Symbiosis between Biodiverse Green Roofs and Renewable Energy, City Green - Verdant Cities 2017, 15, 42-48.

[34] T. Baumann, D. Schär, F. Carigiet, A. Dreisiebner, F. Baumgartner, Performance analysis of PV and Green Roof systems, Proceedings of the $32^{\text {nd }}$ European Photovoltaic Solar Energy Conference and Exhibition, 1618 - 1622.

[35] C. Maurer, C. Cappel, T. E. Kuhn, Progress in building-integrated solar thermal systems, Solar Energy 2017, 154, 158-186.

[36] R. Ciriminna, M. Pecoraino, F. Meneguzzo, M. Pagliaro, Solar Air Heating and Ventilation in Buildings: A Key Component in the Forthcoming Renewable-Only Energy Mix, Energy Technol. 2017, 5, 1165-1172.

[37] B. K. Sovacool, Renewable Energy: Economically Sound, Politically Difficult, Electr. J. 2014, 21, 18-29.

[38] F. Meneguzzo, F. Zabini, R. Ciriminna, M. Pagliaro, Assessment of the Minimum Value of Photovoltaic Electricity in Italy, Energy Sci. Engineer 2014, 2, 94-105

[39] J. Starn, R. Morison, "Free Power on the Cards for German Factories This Christmas", Bloomberg Markets, 22 December 2017. See at the URL: $\quad$ www.bloomberg.com/news/articles/2017-12-22/free-power-onthe-cards-for-german-factories-this-christmas (Accessed: 10 January 2018).

[40] M. Tan, "The Hungry Dragon: Explaining China's 50GW+ PV market in 2017", pv-tech.org, 15 December 2017. See at the URL: https://www.pv-tech.org/guest-blog/the-hungry-dragon-explainingchinas-50gw-pv-market-in-2017 (Accessed: 10 January 2018).
[41] Global Wind Energy Council, Global statistics 2017, See at the URL: http://gwec.net/global-figures/graphs (Accessed: 10 January 2018).

[42] World Nuclear Association, Nuclear Power in the World Today, August 2017. See at the URL: www.world-nuclear.org/informationlibrary/current-and-future-generation/nuclear-power-in-the-worldtoday.aspx (Accessed: 10 January 2018)

[43] S. Castellanos, D. A. Sunter, D. M. Kammen, Rooftop solar photovoltaic potential in cities: how scalable are assessment approaches?, Environ. Res. Lett. 2017, 12, 125005

[44] Solar Power Europe, "Global Solar Market Demand to Reach $100 \mathrm{GW}$ in 2017", Brussels, 26 October 2017. See at the URL: http://www.solarpowereurope.org/media/press-releases/ (Accessed: 10 January 2018).

[45] R. Wüstenhagen, M. Wolsink, M. J. Bürer, Social acceptance of renewable energy innovation: an introduction to the concept, Energy Policy 2007, 35, 2683-2691.

[46] M. Wolsink, The research agenda on social acceptance of distributed generation in smart grids: Renewable as common pool resources, Renew. Sust. Energy Rev. 2012, 16, 822-835.

[47] C. S. Polo López, F. Frontini, Energy Efficiency and Renewable Solar Energy Integration in Heritage Historic Buildings, Energy Procedia 2014, 48, 1493-1502.

[48] R. Ciriminna, F. Meneguzzo, M. Pecoraino, M. Pagliaro, Rethinking Solar Energy Education on the Dawn of the Solar Economy, Renew. Sust. Energy Rev. 2016, 63, 13-18.

[49] K. Farkas, M. Horvat, Report T.41.A.2: Building Integration of Solar Thermal and Photovoltaics - Barriers, Needs and Strategies, IEA SHC Task 41 Solar energy and Architecture, 2012.

[50] C. W. Keck, G. A. Reed, The Curious Case of Cuba, Am. J. Public Health 2012, 102, e13-e22.

[51] M. Castelló González, R. Pons Vásquez, D. Rodriguez Bencomo, I. Choonara, International Medical Collaboration: Lessons from Cuba, Children 2016, 3, 20.

[52] M. Pagliaro, F. Meneguzzo, Que faire? A Bioeconomy and Solar Energy Institute at Italy's Research Council in the Context of the Global Transition to the Solar Economy, Chem. Eur. J. 2017, 23, 15276-15282. 
